\title{
Assessment of Chlorella sorokiniana Growth in Anaerobic Digester Effluent
}

\author{
Elvira E. Ziganshina, Svetlana S. Bulynina and Ayrat M. Ziganshin *
}

check for updates

Citation: Ziganshina, E.E.; Bulynina, S.S.; Ziganshin, A.M. Assessment of Chlorella sorokiniana Growth in Anaerobic Digester Effluent. Plants 2021, 10, 478. https://doi.org/ $10.3390 /$ plants 10030478

Received: 16 December 2020

Accepted: 23 February 2021

Published: 3 March 2021

Publisher's Note: MDPI stays neutral with regard to jurisdictional claims in published maps and institutional affiliations.

Copyright: (c) 2021 by the authors. Licensee MDPI, Basel, Switzerland. This article is an open access article distributed under the terms and conditions of the Creative Commons Attribution (CC BY) license (https:// creativecommons.org/licenses/by/ $4.0 /)$.
Department of Microbiology, Institute of Fundamental Medicine and Biology, Kazan (Volga Region) Federal University, 420008 Kazan, Russia; elvira.ziganshina@kpfu.ru (E.E.Z.); SvSBulynina@stud.kpfu.ru (S.S.B.)

* Correspondence: ayrat.ziganshin@kpfu.ru; Tel.: +7-843-233-7881

\begin{abstract}
Microalgae are considered a potential source of valuable compounds for multiple purposes and are potential agents for bioremediation of aquatic environments contaminated with different pollutants. This work evaluates the use of agricultural waste, unsterilized and anaerobically digested, to produce biomass from a strain of Chlorella sorokiniana. Furthermore, the presence of bacteria in these wastes was investigated based on the bacterial 16S rRNA gene sequencing. The results showed a specific growth rate ranging between 0.82 and $1.45 \mathrm{day}^{-1}$, while the final biomass yield in different digestate-containing treatments (bacterial-contaminated cultures) ranged between 0.33 and $0.50 \mathrm{~g} \mathrm{~L}^{-1} \mathrm{day}^{-1}$. Besides, substantial amounts of ammonium, phosphate, and sulfate were consumed by $C$. sorokiniana during the experimental period. The predominant bacteria that grew in the presence of $C$. sorokiniana in the effluent-containing treatments belonged to the genera Chryseobacterium, Flavobacterium, Sphingomonas, Brevundimonas, Hydrogenophaga, Sphingobacterium, and Pseudomonas. Therefore, this microalga can tolerate and grow in the presence of other microorganisms. Finally, these results show that anaerobically digested agricultural waste materials are a good substitute for growth media for green microalgae; however, phosphate and sulfate levels must also be controlled in the media to maintain adequate growth of microalgae.
\end{abstract}

Keywords: photobioreactor; anaerobic digester effluent; microalgal-bacterial polyculture; Chlorella sorokiniana; bacterial community structure; nutrient removal

\section{Introduction}

Microalgae are deservedly considered promising renewable sources of various valuable compounds-proteins, lipids, pigments, antioxidants, as well as valuable food and feed additives. Microalgae are not only a potential source of nutrients and biologically active compounds for use in the food and pharmaceutical industries but also attract the attention of researchers because of their ability to reduce greenhouse gas emissions and remove inorganic nitrogen, phosphorus, heavy metals, and some toxic organic compounds [1-4]. However, despite the excellent prospects for microalgal biotechnologies, the cost of production and processing of microalgal bioproducts is often a limiting factor for their large-scale implementation. Thus, microalgal biotechnology requires inexpensive water and nutrients for high and stable algal growth rates and increased target products' productivity.

Environmental pollution by various compounds is a big problem everywhere [5,6]. Considering the need to address environmental pollution issues and maintain water resource availability and quality, biological wastewater treatment using microalgae is rapidly developing as an economically and ecologically attractive biotechnology. Many studies to optimize the growth and productivity of microalgae under various regimens have focused on growing microalgae in different nutrient-rich wastewater streams, including municipal [7,8], industrial [9-11], and agricultural wastes [12,13]. It seems possible to use microalgae for the simultaneous achievement of several goals: wastewater treatment, synthesis of valuable metabolic products, and accumulation of algal biomass as feed supplements. Various waste streams that are used as a nutrient medium for growing 
promising microalgae, in addition to valuable nutrients, may contain heavy metals, metalloids, pathogens, and various organic pollutants. The researchers concluded that a few resistant strains of algae could grow and efficiently produce valuable bioproducts in such harsh conditions, given the fact that these substrates can contain large amounts of chemical contaminants and other microorganisms [12-15].

Agricultural wastewater contains different microorganisms that are usually excreted in the feces and urine of farm animals. The abundance and diversity of these microorganisms are the subjects of distinct studies, since their presence in wastewater directly affects the growth rate and productivity of algal cultures, as well as the quality of products obtained from algal biomass. Bohutskyi with colleagues [12,13] proved that only a few algae of the genera Chlorella and Scenedesmus could grow efficiently in the bacterial-contaminated wastewater media. Chlorella species, such as Chlorella vulgaris and Chlorella sorokiniana, are admirable for autotrophic, heterotrophic, and mixotrophic growth. They are actively used for wastewater treatment alone [15-17] or in combination with activated sludge [14,18,19]. Moreover, they belong to the producers of valuable biologically essential compounds such as pigments, lipids, proteins, and carbohydrates [20,21]. Furthermore, extracts of microalgae of the genera Chlorella and Scenedesmus positively affect the germination of root crops [22].

Researchers in this area pay great attention to optimizing the nutritional conditions in order to increase the biomass yield of these photosynthetic microorganisms and the productivity of individual products of their metabolism. A distinctive feature in this area is the search and use of cheap media to cultivate algae. These include wastewater and some products of processing various organic waste materials, particularly wastes generated during the anaerobic digestion process [23,24]. Anaerobic digestion of biomass is a standard process applied to treat a wide range of organic waste materials. Complex microbial communities carry out this process with simultaneous biogas production $[25,26]$. In addition to biogas, the gaseous product of the anaerobic process, effluents (digestates) are generated, which are rich in nitrogen and phosphorus compounds. They can be considered as inexpensive and suitable media for growing microalgae [16,23]. Thus, vast new data on the screening, characterization, and efficient cultivation of green microalgae using affordable and nutrient-rich substrates could significantly increase microalgae productivity for the food, pharmaceutical, and biofuel industries. In our recent work [27], we optimized the nutrients levels and light intensity for the high growth rate of alga C. sorokiniana AM-02 in photoautotrophic growth regimens. Thus, a wide range of nitrate levels $\left(180-1440 \mathrm{mg} \cdot \mathrm{L}^{-1}\right)$ and different photosynthetic photon flux density conditions $\left(1000-1400 \mu \mathrm{mol} \cdot \mathrm{m}^{-2} \cdot \mathrm{s}^{-1}\right)$ were tested on the growth efficiency of $C$. sorokiniana AM-02. We further suggested that this local strain is suitable for enhanced biomass productivity and purification of different wastewater systems.

In this work, we evaluated the growth parameters of C. sorokiniana strain AM-02, as a strain resistant to high concentrations of nutrients and high light intensity, during its cultivation in an unsterilized anaerobic digestion effluent. Growth, the concentration of pigments, $\mathrm{pH}$ of the medium, utilization of nutrients by microalgal culture were investigated throughout the entire experimental period. The optimal cultivation conditions for the effective removal of nutrients were identified. Besides, bacterial 16S rRNA gene fragments were examined to analyze the level of bacterial contamination in the media.

\section{Results and Discussion}

\subsection{Growth of C. sorokiniana AM-02 under Different Conditions}

The growth of microalgae and biomass productivity when grown in wastewater or anaerobic digester effluent depend on different factors (such as the features of the culture, physicochemical properties of the wastes, type of a photobioreactor, and technological parameters of the process) [28]. The microalgal strain Chlorella sorokiniana AM-02 was tested in our previous study [27], in which we identified the optimal growth conditions in a standard Bold's Basal Medium (BBM). In this research, a synthetic medium for supplying 
algae with all the necessary growth compounds was replaced with a diluted anaerobic digester effluent (ADE). Unsterilized effluent after mesophilic anaerobic digestion of cattle manure, distiller grains with solubles, and sugar beet pulp was used for the experiments. ADE was initially centrifuged at $10,000 \times g$ for 10 min to remove sediment and then was used to culture Chlorella sorokiniana strain AM-02.

We studied the effect of different concentrations of digestate $(10,15,20,25$, and $40 \%)$ on the growth of the alga (ADE was diluted in deionized water). These wastes are rich in nitrogen and contain residual organic carbon, which can be used by microalgae. Most of the nitrogen in the digestate was in the form of ammonium and was readily available for algae. It is important to note that high ammonium concentrations are toxic for various microalgae, and ammonium toxicity in water can be due to non-ionized ammonia $\left(\mathrm{NH}_{3}\right)$ and ionized ammonium $\left(\mathrm{NH}_{4}{ }^{+}\right) . \mathrm{NH}_{3}$ is considered the most toxic form for different microalgae, because it is lipid-soluble and diffuses readily through membranes [29]. Besides, a modified BBM with an ammonium nitrogen source was also used to compare growth efficiency. To control the algal growth, the $\mathrm{OD}_{750}$ was measured. Since $\mathrm{OD}_{750}$ also measures bacterial growth, the number of algal cells was further counted (results are shown in Figure 1). The algae were cultured until the stationary phase was reached.
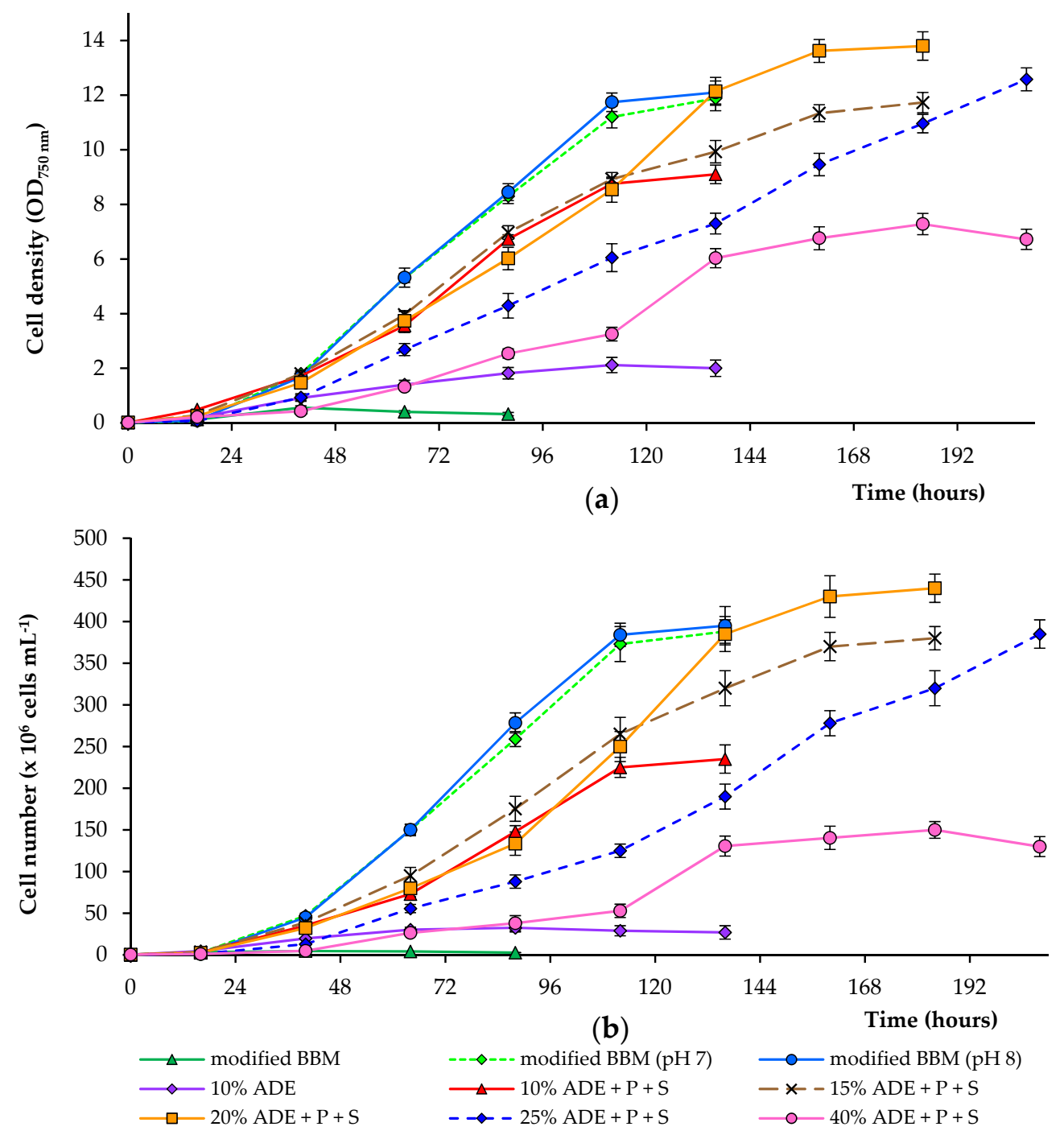

Figure 1. Growth of $C$. sorokiniana $\mathrm{AM}-02\left(\mathrm{OD}_{750}(\mathbf{a})\right.$ and cells $\left.\cdot \mathrm{mL}^{-1}(\mathbf{b})\right)$ cultured under different conditions. 
During the growth of alga C. sorokiniana in $10 \%$ ADE, we noted that, among various other factors, a significant factor is the presence of available phosphate and sulfate ions in diluted ADE. An initial experiment showed that due to a lack of these compounds in diluted effluent, the growth of $C$. sorokiniana strain AM-02 was limited. After adding phosphate (up to $160 \mathrm{mg} \cdot \mathrm{L}^{-1}$ ) and sulfate (up to $40 \mathrm{mg} \cdot \mathrm{L}^{-1}$ ) to the diluted effluent, all critical parameters were significantly improved (Figure 1; Tables 1 and 2). Higher growth and biomass production were observed when the medium contained $10-40 \%$ digestate with additional phosphate and sulfate ions.

Table 1. C. sorokiniana culture characteristics and nutrient removal from Bold's Basal Medium (BBM) and diluted anaerobic digester effluent (ADE).

\begin{tabular}{|c|c|c|c|c|}
\hline Treatment & $\begin{array}{l}\text { Dry Weight } \\
\quad\left(g \cdot L^{-1}\right)\end{array}$ & $\begin{array}{l}\text { Volatile Solids } \\
\qquad\left(\mathrm{g} \cdot \mathrm{L}^{-1}\right)\end{array}$ & $\begin{array}{c}\mathrm{PO}_{4}{ }^{3-} \text { Removal } \\
(\%)\end{array}$ & $\begin{array}{c}\mathrm{SO}_{4}{ }^{2-} \text { Removal } \\
(\%)\end{array}$ \\
\hline $\begin{array}{l}\text { modified BBM } \\
\qquad(\mathrm{pH} \mathrm{7})\end{array}$ & $2.80 \pm 0.11^{b, c}$ & $2.59 \pm 0.07^{b}$ & $69.1 \pm 4.2^{\mathrm{c}, \mathrm{d}}$ & $81.2 \pm 8.8^{a, b}$ \\
\hline $\begin{array}{l}\text { modified BBM } \\
(\mathrm{pH} 8)\end{array}$ & $2.83 \pm 0.14^{\mathrm{a}, \mathrm{b}, \mathrm{c}}$ & $2.62 \pm 0.11^{b}$ & $71.0 \pm 4.9^{b, c, d}$ & $82.5 \pm 10.6^{\mathrm{a}, \mathrm{b}}$ \\
\hline $10 \% \mathrm{ADE}$ & $0.44 \pm 0.04^{\mathrm{e}}$ & $0.41 \pm 0.04^{\mathrm{d}}$ & $100^{a}$ & $100^{a}$ \\
\hline $10 \% \mathrm{ADE}+\mathrm{P}+\mathrm{S}$ & $1.88 \pm 0.08^{\mathrm{d}}$ & $1.76 \pm 0.08^{c}$ & $49.7 \pm 3.6^{\mathrm{e}}$ & $62.5 \pm 9.7^{b}$ \\
\hline $15 \% \mathrm{ADE}+\mathrm{P}+\mathrm{S}$ & $2.73 \pm 0.12^{\mathrm{c}}$ & $2.56 \pm 0.14^{b}$ & $66.3 \pm 4.0^{\mathrm{d}}$ & $75.1 \pm 8.5^{\mathrm{a}, \mathrm{b}}$ \\
\hline $20 \% \mathrm{ADE}+\mathrm{P}+\mathrm{S}$ & $3.35 \pm 0.21^{\mathrm{a}, \mathrm{b}}$ & $3.12 \pm 0.17^{\mathrm{a}}$ & $75.3 \pm 3.8^{b, c, d}$ & $92.5 \pm 7.1^{\mathrm{a}, \mathrm{b}}$ \\
\hline $25 \% \mathrm{ADE}+\mathrm{P}+\mathrm{S}$ & $3.39 \pm 0.23^{\mathrm{a}}$ & $3.20 \pm 0.20^{a}$ & $82.2 \pm 2.9^{b, c}$ & $100^{\mathrm{a}}$ \\
\hline $40 \% \mathrm{ADE}+\mathrm{P}+\mathrm{S}$ & $2.51 \pm 0.09^{c}$ & $2.36 \pm 0.10^{b}$ & $85.1 \pm 2.7^{b}$ & $77.5 \pm 10.6^{a, b}$ \\
\hline
\end{tabular}

Different superscripts indicate differences between the treatments (ANOVA, Tukey method, $\alpha=0.05$ ). Means that do not share a letter are significantly different.

Table 2. C. sorokiniana culturing characteristics when grown under different conditions.

\begin{tabular}{|c|c|c|c|c|}
\hline Treatment & $\begin{array}{c}\text { Specific Growth } \\
\text { Rate } \\
\left(\mathrm{Day}^{-1}\right)\end{array}$ & $\begin{array}{c}\text { Biomass } \\
\text { Productivity } \\
\left(\mathrm{g} \cdot \mathrm{L}^{-1} \cdot \text { Day }^{-1}\right)\end{array}$ & $\begin{array}{l}\text { Maximum } \\
\text { Pigments } \\
\left(\mathrm{mg} \cdot \mathrm{L}^{-1}\right)\end{array}$ & $\begin{array}{l}\text { Final Pigments } \\
\text { (\% Dry Weight) }\end{array}$ \\
\hline $\begin{array}{c}\text { modified BBM } \\
(\mathrm{pH} 7)\end{array}$ & $1.50 \pm 0.01^{\mathrm{a}}$ & $0.60 \pm 0.02^{a}$ & $80.5 \pm 3.0^{\mathrm{c}}$ & $2.73 \pm 0.21^{\mathrm{c}}$ \\
\hline $\begin{array}{l}\text { modified BBM } \\
(\mathrm{pH} 8)\end{array}$ & $1.51 \pm 0.01^{\mathrm{a}}$ & $0.60 \pm 0.03^{a}$ & $86.9 \pm 4.0^{\mathrm{c}}$ & $2.78 \pm 0.28^{c}$ \\
\hline $10 \% \mathrm{ADE}$ & $1.15 \pm 0.03^{c}$ & $0.09 \pm 0.01^{\mathrm{d}}$ & $4.6 \pm 0.7^{\mathrm{e}}$ & $1.02 \pm 0.06^{\mathrm{d}}$ \\
\hline $10 \% \mathrm{ADE}+\mathrm{P}+\mathrm{S}$ & $1.45 \pm 0.01^{b}$ & $0.40 \pm 0.02^{c}$ & $60.9 \pm 5.4^{\mathrm{d}}$ & $2.76 \pm 0.11^{c}$ \\
\hline $15 \% \mathrm{ADE}+\mathrm{P}+\mathrm{S}$ & $1.06 \pm 0.01^{\mathrm{d}}$ & $0.41 \pm 0.02^{\mathrm{c}}$ & $95.8 \pm 6.4^{\mathrm{c}}$ & $2.97 \pm 0.23^{c}$ \\
\hline $20 \% \mathrm{ADE}+\mathrm{P}+\mathrm{S}$ & $1.08 \pm 0.01^{\mathrm{d}}$ & $0.50 \pm 0.03^{b}$ & $124.5 \pm 5.6^{b}$ & $3.58 \pm 0.31 \mathrm{~b}, \mathrm{c}$ \\
\hline $25 \% \mathrm{ADE}+\mathrm{P}+\mathrm{S}$ & $0.82 \pm 0.01^{\mathrm{e}}$ & $0.39 \pm 0.03^{c}$ & $160.4 \pm 4.2^{\mathrm{a}}$ & $4.49 \pm 0.29^{a, b}$ \\
\hline $40 \% \mathrm{ADE}+\mathrm{P}+\mathrm{S}$ & $0.86 \pm 0.02{ }^{\mathrm{e}}$ & $0.33 \pm 0.01^{\mathrm{c}}$ & $124.1 \pm 6.2^{b}$ & $4.95 \pm 0.10^{\mathrm{a}}$ \\
\hline
\end{tabular}

Different superscripts indicate differences between the treatments (ANOVA, Tukey method, $\alpha=0.05$ ). Means that do not share a letter are significantly different.

Adding phosphate and sulfate and increasing the concentration of ADE in the culture medium from 10 to $20 \%$ led to an increase in $\mathrm{OD}_{750}$ and cell numbers. Overall, $\mathrm{OD}_{750}$ correlated with the calculated cell count. The optical density changes were also due to bacterial cells' growth on effluent components. Still, the main reason for $\mathrm{OD}_{750}$ change was the growth of microalgae, since the abundance of bacteria was low compared with the abundance of algal cells (data not shown). The cultures in experiments supplied with $10 \%$ ADE increased in mean $\mathrm{OD}_{750}$ values and cell number until stationary growth was achieved at 8.9 and $2.3 \times 10^{8}$ cells. $\mathrm{mL}^{-1}$ (after $112 \mathrm{~h}$ ), respectively. In comparison, in treatments supplied with $20 \% \mathrm{ADE}$, the cultures increased in mean $\mathrm{OD}_{750}$ values and cell number to 13.6 and $4.3 \times 10^{8}$ cells. $\mathrm{mL}^{-1}$ (after $160 \mathrm{~h}$ ), respectively.

Further expanding the ADE concentration in the culture medium from 20 to $40 \%$ led to a decrease in mean $\mathrm{OD}_{750}$ values and cell numbers compared to the previous experiments. The cultures in treatments supplied with $25 \%$ ADE reached mean $\mathrm{OD}_{750}$ values and cell 
number at 12.6 and $3.9 \times 10^{8}$ cells $\cdot \mathrm{mL}^{-1}$ (after $208 \mathrm{~h}$ ), respectively. In contrast, in treatments supplied with $40 \% \mathrm{ADE}$, the cultures achieved mean $\mathrm{OD}_{750}$ values and cell number until stationary growth was achieved at 7.3 and $1.5 \times 10^{8}$ cells $\cdot \mathrm{mL}^{-1}$ (after $184 \mathrm{~h}$ ), respectively. Cultivation in modified BBM (with controlled pH levels of 7.0 and 8.0) was similar but showed better growth characteristics compared to those observed in diluted effluents. Cultivation in modified BBM without $\mathrm{pH}$ control resulted in a rapid drop in the medium's $\mathrm{pH}$ and complete growth inhibition (Figure 1).

Key parameters of the different growth conditions, including dry weight, volatile solids, specific growth rate, biomass productivity, and maximum pigments, were determined, and these data are displayed in Tables 1 and 2. C. sorokiniana strain AM-02 grown in $10 \%$ ADE without and with the addition of phosphate and sulfate reached maximal mean biomass concentrations of 0.44 and $1.88 \mathrm{~g} \cdot \mathrm{L}^{-1}$, respectively. These data were significantly lower than the values obtained in modified BBM $\left(2.8 \mathrm{~g} \cdot \mathrm{L}^{-1}\right)$. C. sorokiniana AM-02 maintained in 20 and $25 \%$ ADE with the addition of phosphate and sulfate reached a maximal mean biomass concentration of $3.35-3.39 \mathrm{~g} \cdot \mathrm{L}^{-1}$. These values were higher than the values observed in modified BBM, but statistically insignificant. During the first days, a high foam generation started in the photobioreactor with $40 \%$ effluent loading (despite the addition of antifoam). Higher levels of dry matter in these treatments can be explained by the immobilization of algal cells and the formation of biofilms on the reactor's inner surfaces in the air phase (after the foam level decreased), which were also collected after the experiment.

The mean specific growth rates of $C$. sorokiniana strain AM-02 were 1.45, 1.06, 1.08, 0.82 , and 0.86 day $^{-1}$ in $10 \% \mathrm{ADE}, 15 \% \mathrm{ADE}, 20 \% \mathrm{ADE}, 25 \% \mathrm{ADE}$, and $40 \% \mathrm{ADE}$ with the addition of phosphate and sulfate, respectively. However, these values were significantly lower than those values observed during the growth of C. sorokiniana in modified BBM (1.501.51 day $^{-1}$ ). The highest growth rate of 1.45 day $^{-1}$ was obtained with $10 \%$ effluent loading compared to other ADE-containing treatments. The mean biomass productivities were 0.40 , $0.41,0.50,0.39$, and $0.33 \mathrm{~g} \cdot \mathrm{L}^{-1}$. day $^{-1}$ in $10 \% \mathrm{ADE}, 15 \% \mathrm{ADE}, 20 \% \mathrm{ADE}, 25 \% \mathrm{ADE}$, and $40 \%$ ADE with the addition of phosphate and sulfate ions, accordingly. Values observed in ADEcontaining treatments were significantly lower than those observed during C. sorokiniana cells' growth in modified BBM $\left(0.60 \mathrm{~g} \cdot \mathrm{L}^{-1} \cdot \mathrm{day}^{-1}\right)$. The highest biomass productivity of $0.50 \mathrm{~g} \cdot \mathrm{L}^{-1} \cdot$ day $^{-1}$ was obtained with $20 \%$ effluent loading compared to other ADEcontaining experiments.

Figure 2 demonstrates the concentrations of chlorophyll $a$, chlorophyll $b$, and total carotenoids in algal cells cultured under various experimental conditions. Thus, the final pigment concentration in algal cells cultured in 20-40\% ADE was significantly higher than that observed in cells cultured in modified BBM (Table 2). Culturing of alga in $25 \% \mathrm{ADE}$ resulted in the highest pigment concentration, and the mean chlorophyll $a$, chlorophyll $b$, and total carotenoids reached $99.5,38.3$, and $22.7 \mathrm{mg} \cdot \mathrm{L}^{-1}$ under these conditions, respectively. The mean chlorophyll $a$, chlorophyll $b$, and total carotenoids reached 51.4, 18.2, and $10.9 \mathrm{mg} \cdot \mathrm{L}^{-1}$ during culturing in modified BBM, accordingly (at $\mathrm{pH}$ 7.0) (Figure 2).

The slower growth of different green microalgae in various agricultural wastewaters is also due to their dark color. The high level of total solids in different digestates and the intense black color of non-diluted effluents reduce light penetration into the culture medium and, thereby, hinder microalgal growth and reduce the rate of nutrient recovery from wastewaters as was shown previously [30,31]. According to previous studies, the medium's dark color lowers the algal cellular productivity compared to a non-colored culture medium $[17,31,32]$.

This research showed that microalgae's successful growth in diluted anaerobic digester effluent was believed to be due to the improved light transmission and reduced ammonia (and possibly other components) toxicity. In several research works, light limitation and ammonia toxicity have been avoided by diluting the wastewater with clean water $[17,32,33]$. 
Centrifugation of the digestate contributed to removing particles as well, which gave it a dark color.

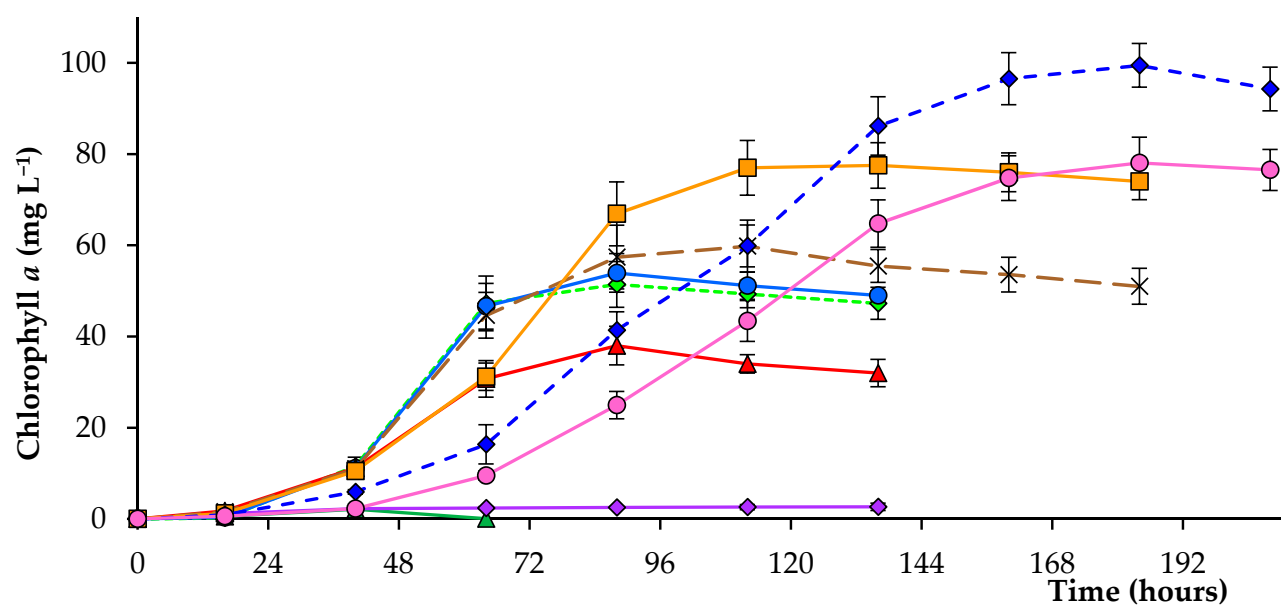

(a)

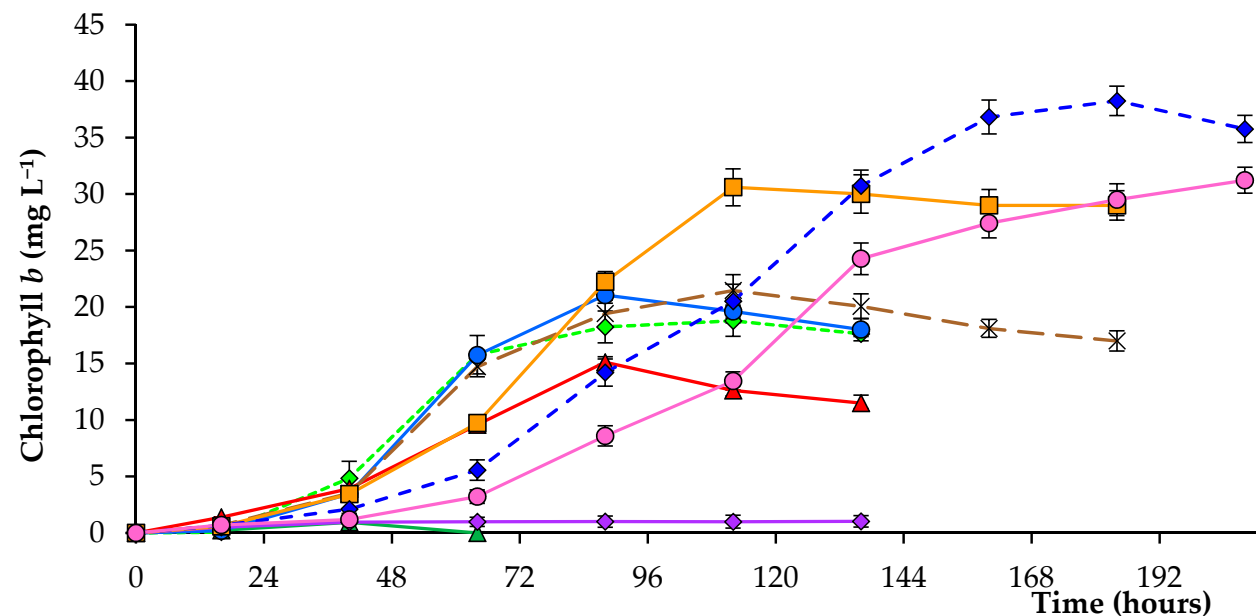

(b)

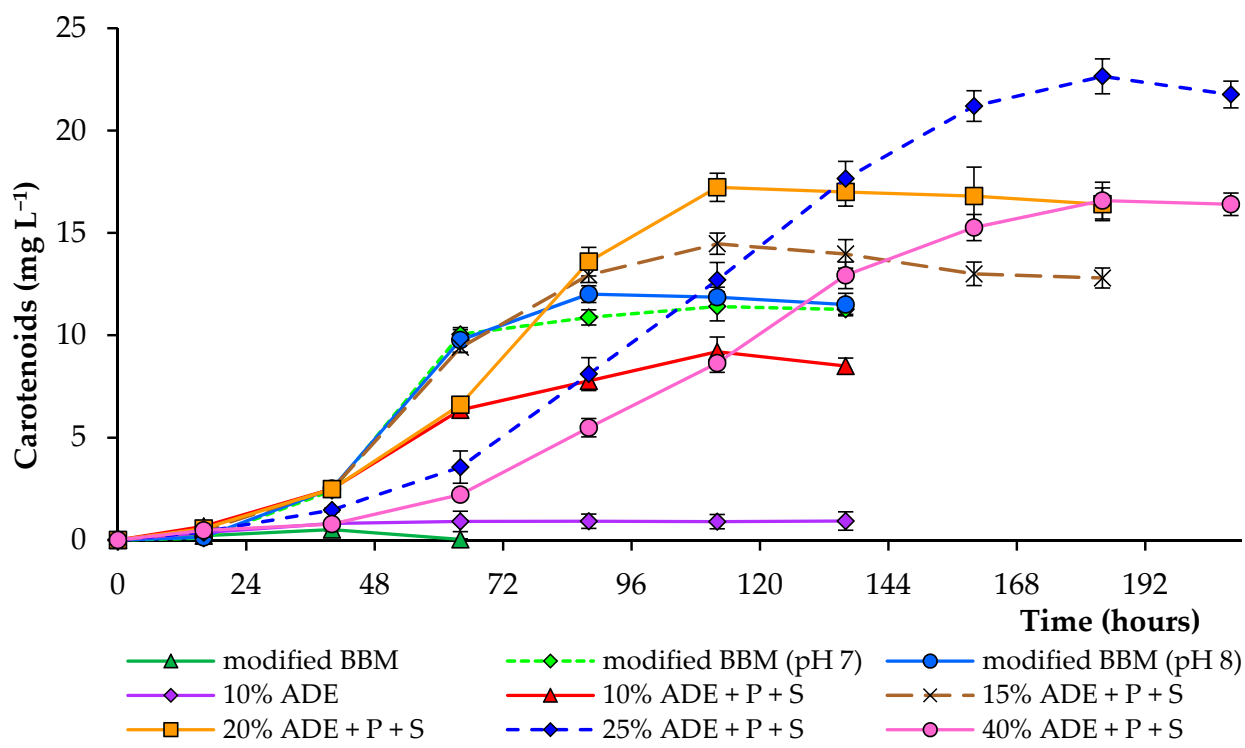

(c)

Figure 2. Pigment concentration (chlorophyll $a(\mathbf{a})$, chlorophyll $b(\mathbf{b})$, and carotenoids (c)) in cells of C. sorokiniana AM-02 cultured under different conditions. 
Previous work results showed that the preferred high levels of photosynthetic photon flux density for C. sorokiniana strain AM-02 in standard BBM are 1000-1400 $\mu$ mol of photons $\mathrm{m}^{-2} \cdot \mathrm{s}^{-1}$ [27]. Therefore, we chose $1200 \mu \mathrm{mol}$ of photons $\mathrm{m}^{-2} \cdot \mathrm{s}^{-1}$ in the present study. Under such conditions, microalgae should receive enough light, since the addition of digestate increases the medium's turbidity. Moreover, we continuously sparged cultures with air supplemented with $2 \% \mathrm{CO}_{2}$, since it was found that nutrients are consumed faster under these conditions [27].

Figure 3 shows the changes in $\mathrm{pH}$ under different cultivation conditions. The higher ADE content resulted in a higher initial $\mathrm{pH}$ of the medium. During cultivation in various diluted anaerobic digester effluents, the $\mathrm{pH}$ decreased from initial values of 7.5-8.0 to about 7.3-7.9, depending on the experimental condition. In the experiments with modified BBM, $\mathrm{pH}$ dropped from an initial 6.1 to 3.2 within $40 \mathrm{~h}$ during the cultivation of C. sorokiniana strain AM-02, which completely inhibited the alga growth. Ammonium nutrition leads to a liberation of $\mathrm{H}^{+}$and a decrease in the medium's $\mathrm{pH}$ [29]. Under $\mathrm{pH}$-controlled conditions, growth characteristics in modified BBM were utterly identical, regardless of $\mathrm{pH} 7.0$ or 8.0 (Figure 3).

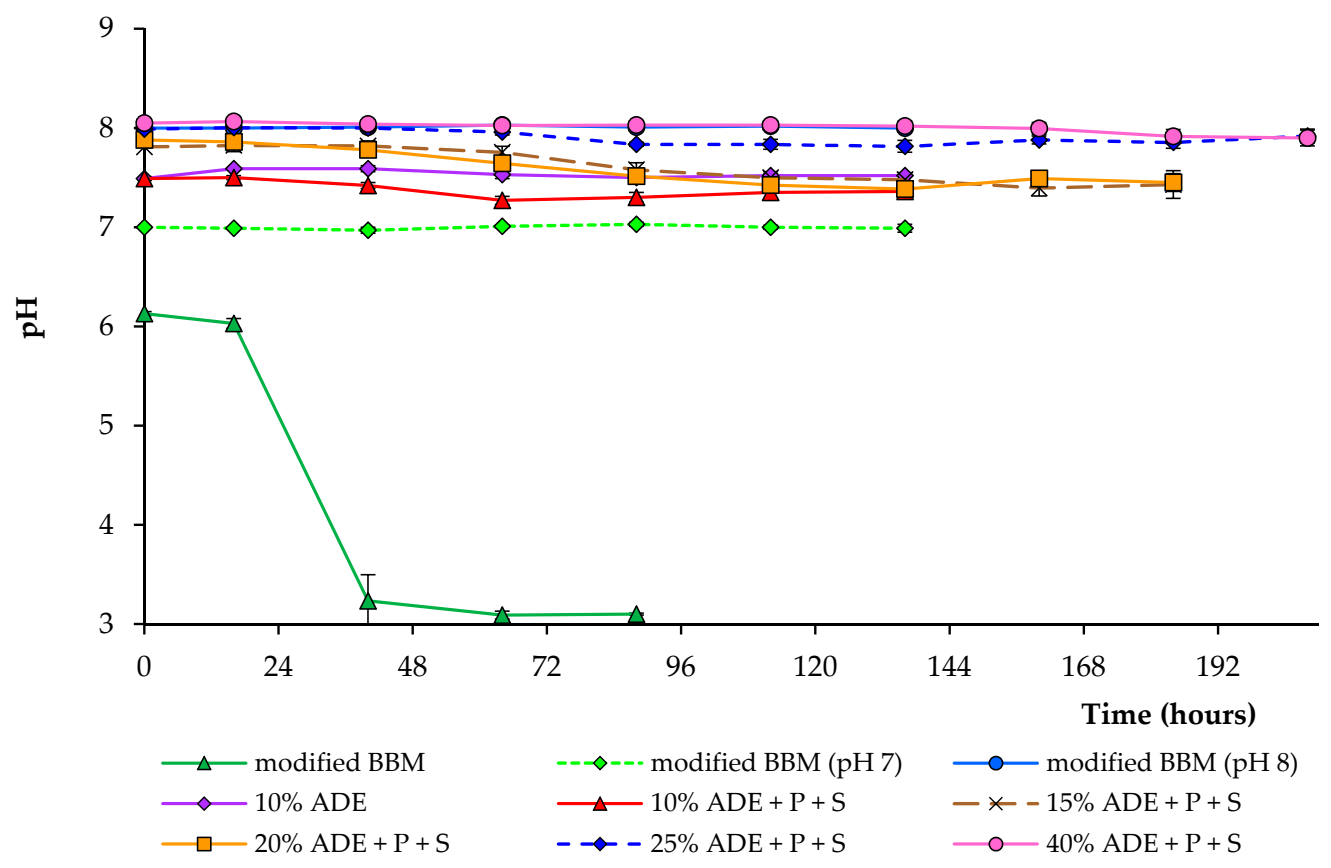

Figure 3. $\mathrm{pH}$ changes during the growth of $\mathrm{C}$. sorokiniana AM-02 under different conditions.

Various nitrogen sources in nutrient media promote the growth of microalgae [34-37]. At non-toxic concentrations, ammonium has been reported to induce higher growth rates than nitrate and urea for many different microalgae species [29]. As previously indicated, the ammonium removal efficiency varies depending on the media composition and environmental conditions, such as the initial concentration of nutrients, light intensity, light/dark cycle, as well as algae species [38]. Most of the nitrogen in the digestate in this study was in the form of an ammonium. Comparison of ammonium removal during the entire experimental period at different digestate concentrations is shown in Figure 4.

In this study, the initial values of the ammonium content in the medium varied depending on the treatment. When cultivating algal cells in a medium loading with $10 \%$ digestate, only $17 \%$ of ammonium was removed after $112 \mathrm{~h}$. Still, when additional nutrients were added to the growth medium, 99\% of ammonium was removed after $112 \mathrm{~h}$. All subsequent experiments were carried out with the addition of phosphate and sulfate at the same concentration. A similar trend was observed using 15, 20, and 25\% diluted ADE (99\% removal after 136-184 h). With an increase in ADE loading to 40\%, 
ammonium removal reached $80 \%$ after $208 \mathrm{~h}$. The rapid $\mathrm{NH}_{4}{ }^{+}$removal efficiency was achieved after 88-112 h in modified BBM ( $\mathrm{pH}$-controlled conditions) and 10-20\% ADE (with added phosphate and sulfate ions). Our results also show that a high phosphate and sulfate removal level is possible (Table 1). However, the partial removal of phosphate in ADE-containing treatments could also be due to some phosphate minerals' precipitation. These findings indicate that C. sorokiniana AM-02 is incredibly tolerant to high ammonium levels. Hence, it has a potential role in removing high amounts of ammonium, phosphate, and sulfate from wastewater. However, an additional contribution to the removal of nutrients in ADE-containing treatments was made by bacteria that grew in the presence of C. sorokiniana.

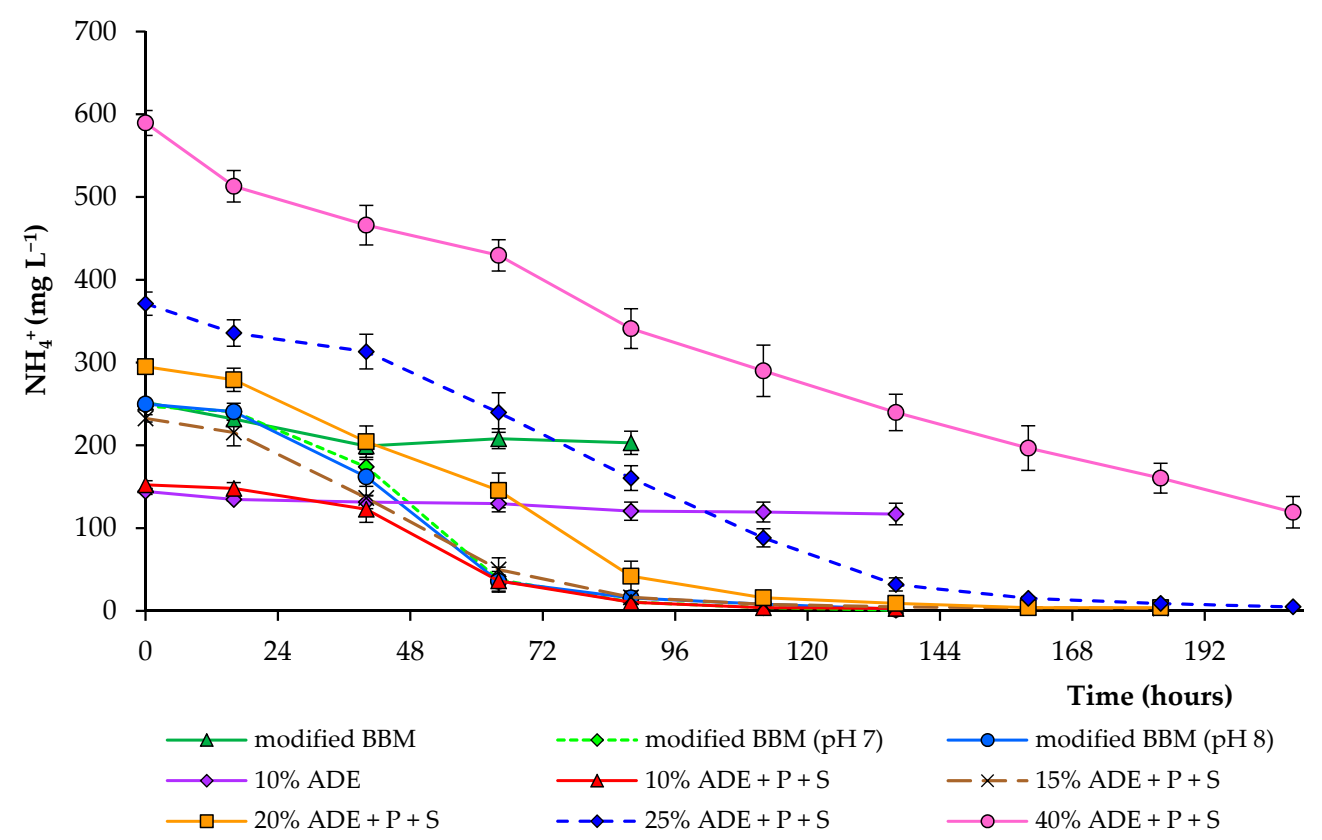

Figure 4. Ammonium concentrations in modified BBM and diluted ADE during the growth of $C$. sorokiniana AM-02.

Even though the abundance of various essential compounds in different wastewaters and anaerobic digesters effluent makes it suitable for microalgae cultivation, it contains other microorganisms, which can compete with microalgae cells. Therefore, most studies cultivated microalgae in sterilized wastewater $[11,36,38]$. However, various sterilization methods can increase the cost of culturing of microalgae and are economically impractical for large-scale cultivation. In this research, ADE was pretreated by centrifugation to remove sediment and improve light transmission (however, for large-scale cultivation, other methods should also be considered). This method also removed most of the microorganisms; however, a minor part was still present in pretreated ADE. The influence of various microorganisms on the growth of $C$. sorokiniana AM-02 was studied in such an environment to develop effective methods for large-scale cultivation of microalgae in multiple wastewaters. It is imperative to screen for resistant microalgae species that can tolerate and grow effectively in such environments, removing nutrients and producing biomass, and in the presence of other competing microorganisms.

Among the studies describing microalgae cultivation in such wastewater systems, the following examples should be mentioned. Bohutskyi et al. [13] found that C. sorokiniana and Scenedesmus acutus are characterized by higher growth rates, productivity, and resistance than other microalgal species when grown in diluted wastewaters samples. Chen et al. [15] demonstrated that the highest biomass concentration $\left(5.45 \mathrm{~g} \cdot \mathrm{L}^{-1}\right)$ by C. sorokiniana AK1 could be obtained after 15 days when maintained in 50\% strength swine wastewater, preliminary pretreated by filtration to remove sediments. Kobayashi et al. [16] investigated 
the growth of three Chlorella sorokiniana strains in 10\% anaerobic digester effluent obtained from cattle manure digestion. ADE was pretreated by centrifugation in their research. Biomass was produced at a concentration of about $270 \mathrm{mg} \cdot \mathrm{L}^{-1}$ by the strains UTEX 1230 and CS-01 (after 21 days) but inhibited the growth of the strain UTEX 2714 by more than $50 \%$ in the ADE. Lizzul et al. [36] found that the final biomass yield of C. sorokiniana UTEX1230 cultured in different wastewater samples that were autoclaved and diluted to $10 \%$ ranged between 220 and $320 \mathrm{mg} \cdot \mathrm{L}^{-1}$. However, the bacterial community structure in these experiments was not investigated. In our work, we show higher biomass productivity compared to the results mentioned above. Our results indicate that C. sorokiniana AM-02 is a good candidate for simultaneous wastewater treatment and biomass production.

\subsection{Bacterial Community Structure}

Algal systems consume nutrients more efficiently and provide oxygen to the aerobic bacteria [39]. Some studies demonstrate the possibility of different symbiotic relationships between microalgae and bacteria. These relationships' nature is still mostly unknown, but there is evidence that most of such relationships allow algae and bacteria to exchange essential metabolites. Although the possibility of developing close relationships in different growth systems has been previously shown, there is little research regarding the impact of these relationships on biomass productivity or the ability to occupy a specific ecological niche [40].

Five samples were taken from several of our ADE-containing systems to analyze bacterial communities' structure developed during the experimental period (at last days). More than 400,000 high-quality bacterial sequences were obtained, and the average number of reads per sample was 80,368 (from 65,191 to 94,835). In general, sequencing of amplicons covered most bacterial phylotypes, which were observed in five samples. The alpha diversity indices (operational taxonomic units (OTUs), Chao1 index, Shannon index, Simpson index) calculated on the OTU level for each sample are demonstrated in Table 3. The number of bacterial OTUs in five samples ranged from 55 to 61 (abundance $>0.1 \%$ ), and their number was comparable in all ADE-containing treatments. However, their abundance was low in comparison with algal cells (data not shown).

Table 3. Alpha diversity of bacterial communities.

\begin{tabular}{ccccc}
\hline Treatment & Observed OTUs & Chao1 & Shannon & Simpson \\
\hline $15 \%$ ADE + P + S & 60 & 62 & 3.99 & 0.86 \\
$20 \%$ ADE + P + S & 59 & 59 & 3.64 & 0.85 \\
$25 \%$ ADE_1 + P + S & 55 & 55 & 3.59 & 0.86 \\
$25 \%$ ADE_2 + P + S & 61 & 61 & 3.74 & 0.85 \\
$40 \%$ ADE + P + S & 61 & 62 & 3.69 & 0.84 \\
\hline
\end{tabular}

The relative abundance of different bacteria that grew in the presence of $C$. sorokiniana AM-02 has been investigated on different taxonomic levels, such as phylum, class, order, family, and genus. Thus, two phyla, three classes, eleven orders, sixteen families, and twenty-six genera were detected in five samples. The structure of bacterial communities (on the phylum, order, and genus levels) in different treatments is presented in Figure 5. The predominant bacterial phyla in the treatments containing ADE were Bacteroidetes and Proteobacteria, which accounted for 51 and $49 \%$ of the total bacterial 16S rRNA gene sequences, respectively (Figure 5a). The predominant bacterial orders in the ADE-containing treatments were Flavobacteriales, Betaproteobacteriales, Sphingomonadales, Sphingobacteriales, Pseudomonadales, and Cauobacterales, which accounted for 37, 12, 11, 10, 10, and 9\% of the total bacterial 16S rRNA gene sequences, accordingly (Figure $5 \mathrm{~b}$ ). The relative abundance of members belonging to the phylum Proteobacteria decreased, while the relative abundance of representatives affiliated with the phylum Bacteroidetes increased with ADE concentration (Figure 5a). 


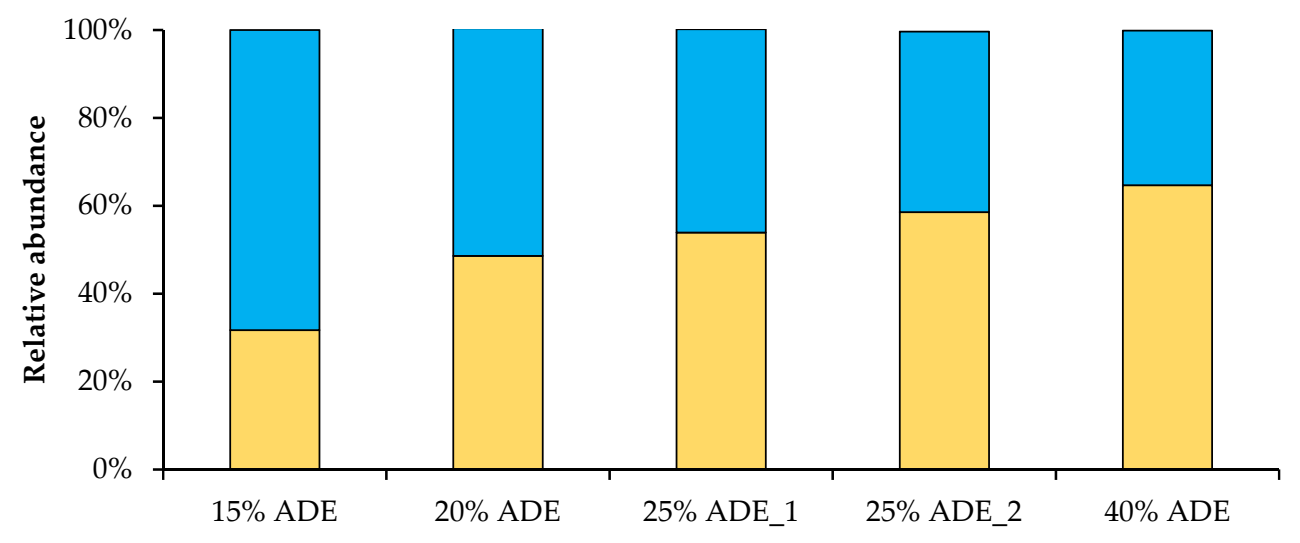

$\square$ Bacteroidetes $\square$ Proteobacteria

(a)

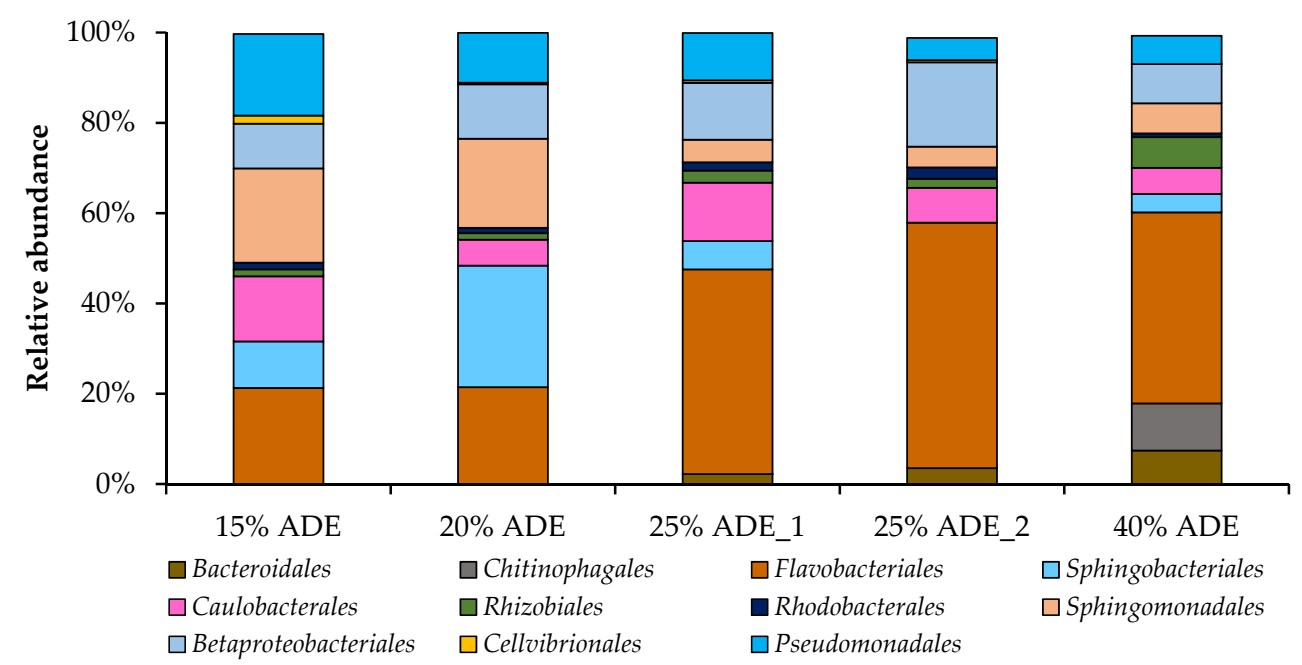

(b)

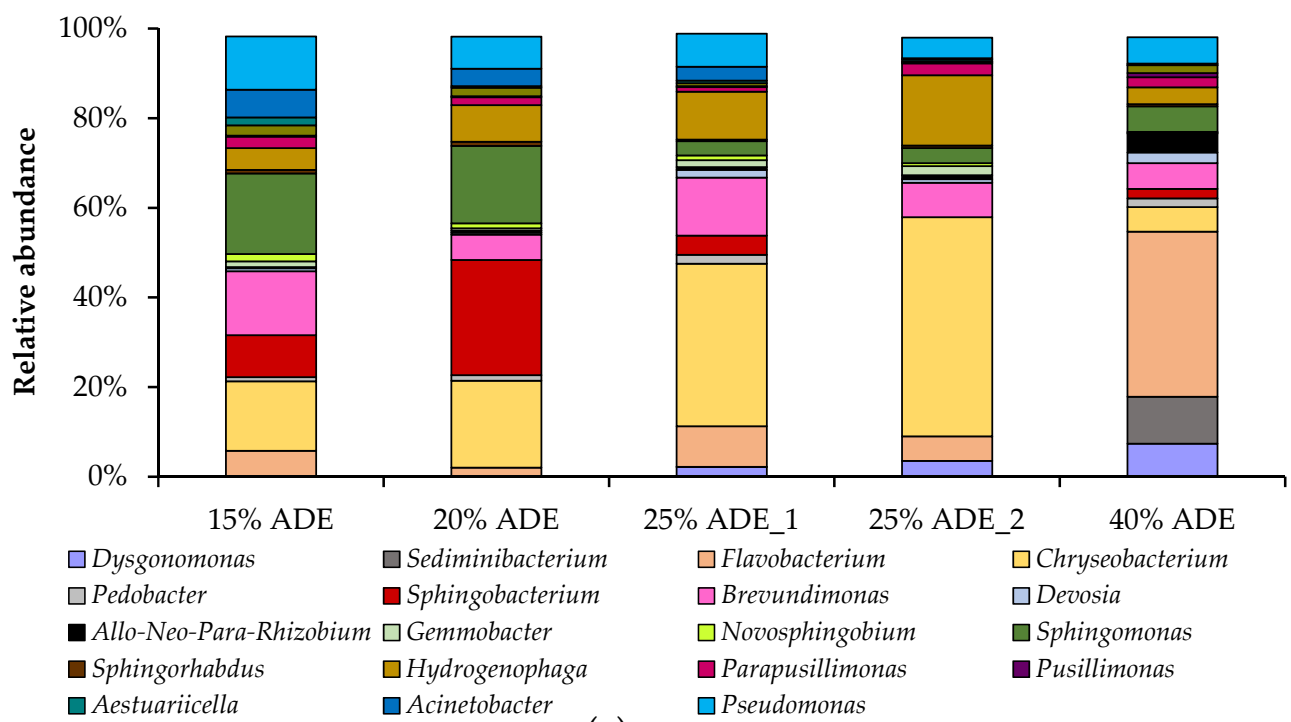

(c)

Figure 5. Taxonomic composition of bacterial communities in the bioreactor during C. sorokiniana AM-02 cultivation in ADE-containing media (15\% ADE (184 h), 20\% ADE (184 h), 25\% ADE_1 (160 h), $25 \%$ ADE_2 (208 h), and 40\% ADE (208 h)). Bacterial community composition according to amplicon sequencing of the bacterial 16S rRNA gene is shown on the phylum (a), order (b), and genus (c) levels. Only genera with a relative abundance of at least $1 \%$ in at least one sample are shown. 
The predominant bacterial genera in the treatments loaded with 15\% ADE were Sphingomonas, Chryseobacterium, Brevundimonas, Pseudomonas, and Sphingobacterium (sampled on $184 \mathrm{~h}$ ). The prevailed bacterial genera in 20\% ADE-containing treatments were Sphingobacterium, Chryseobacterium, Sphingomonas, Hydrogenophaga, and Pseudomonas (sampled on $184 \mathrm{~h}$ ). The predominant genera in $25 \%$ ADE treatments were Chryseobacterium, Brevundimonas, Hydrogenophaga, Flavobacterium, and Pseudomonas (sampled on $160 \mathrm{~h}$ (ADE_1) and $208 \mathrm{~h}$ (ADE_2)). The predominant genera in 40\% ADE-containing experiments were Flavobacterium, Sediminibacterium, Dysgonomonas, Brevundimonas, Sphingomonas, and Pseudomonas (sampled on $208 \mathrm{~h}$ ) (Figure 5c).

Members of the genus Sphingomonas are aerobic bacteria that are ubiquitous in the environment, including water, soil, and activated sludge. Sphingomonads are used for a wide range of biotechnological applications, from the bioremediation of environmental pollutants to the production of extracellular polymers for food and other industries [41]. Species of the aerobic genus Sphingobacterium have mainly been isolated from soil, compost, sludge, plants, raw milk, and water [42]. They are also involved in biodegradation processes [43]. Brevundimonas species are aerobic and are widespread in the environment, including soils, activated sludge, aquatic habitats, and clinical specimens [44]. Some of them are considered potential candidates for remediation of sites contaminated with diesel, n-alkanes, and polycyclic aromatic hydrocarbons [45,46]. Species of the Chryseobacterium are aerobic and producing flexirubin pigments, which give the colonies a light yellow or yellowish-orange color. They can be isolated from various habitats and involved in remediation processes [47]. Pseudomonas spp. are aerobic and excellent bacteria for use in bioremediation processes due to the flexibility and plasticity of their metabolic pathways [48]. Hydrogenophaga species possess oxidative metabolism and can be isolated from activated sludge and wastewater systems [49]. Members of the genus Flavobacterium are aerobic and distributed widely in nature [50]. Besides, bacteria that are used for bioremediation processes include members of the genera Pseudomonas, Sphingomonas, Chryseobacterium, as well as Flavobacterium [51]. Most of these bacteria were also detected as main representatives of microbial communities in other algae-bacteria systems that grew in other wastewater systems [52] and freshwater reactors [53]. Interestingly, representatives of the orders Rhizobiales, Betaproteobacteriales, and Chitinophagales correlated with biomass productivity of C. sorokiniana strain DOE1412 during outdoor cultivation [53].

Bacteria from biogas reactors are mostly strictly anaerobes and facultative anaerobes, and the small part of these anaerobic bacteria that remained after the pretreatment of ADE was quickly replaced by aerobic microflora (still present in effluent and from different sources during effluent preparation) during algae growth. Some bacteria that grew in the presence of $C$. sorokiniana AM-02 were also found in the initial effluent $[54,55]$. It can be assumed that these bacteria, better than other microbes, adapted to the constructed environment, and some of them favorably coexisted with microalgae cells, for example, during the acquisition and exchange of essential metabolites. The investigation of the microbial community structure in algal/bacterial systems provides a necessary insight into various water body systems that can be used to control algal biomass productivity and algal health in non-sterile environments.

\section{Materials and Methods}

\subsection{Digestate-Based Media Preparation}

Effluent from mesophilic batch digesters after anaerobic digestion of cattle manure, rye distiller's grains with solubles, and sugar beet pulp was selected to test the growth of the microalga. Initially, the anaerobic digester effluent (ADE) was centrifuged at $10,000 \times g$ for $10 \mathrm{~min}$ to remove sediment, diluted with deionized water to different concentrations $(10-40 \% v / v)$, and then used to cultivate Chlorella sorokiniana strain AM-02. In experiments with the addition of phosphate ion and sulfate ion, $\mathrm{K}_{2} \mathrm{HPO}_{4}$ and $\mathrm{H}_{2} \mathrm{SO}_{4}$ were added to the diluted effluent to reach standard concentrations as in Bold's Basal Medium (BBM) 
( $160 \mathrm{mg} \cdot \mathrm{L}^{-1}$ and $\sim 40 \mathrm{mg} \cdot \mathrm{L}^{-1}$ for phosphate and sulfate ions, respectively). Before the start of the experiments, ADE was stored at $+4^{\circ} \mathrm{C}$.

Digestate for all treatments was initially analyzed to determine $\mathrm{pH}$, total solids (TS), volatile solids (VS), and concentrations of total volatile fatty acids (VFA), as described in detail previously $[54,55]$. Phosphate and sulfate concentrations in the digestate were analyzed as described before [27]. Thus, initial ADE had the TS content of $4.9 \pm 0.14 \%$, VS content of $3.6 \pm 0.11 \%$, $\mathrm{pH}$ of $8.0 \pm 0.05$, and VFA concentration of $0.54 \pm 0.05 \mathrm{~g} \cdot \mathrm{L}^{-1}$. Pretreated $100 \%$ ADE had initial phosphate and sulfate levels of $52.3 \pm 1.6 \mathrm{mg} \cdot \mathrm{L}^{-1}$ and $5.7 \pm 0.7 \mathrm{mg} \cdot \mathrm{L}^{-1}$, respectively. All these parameters were measured in triplicate, and the mean values are presented together with the standard deviations.

\subsection{Cultivation Conditions in a Photobioreactor}

C. sorokiniana AM-02 was isolated from a local freshwater lake, and the characteristics of its photoautotrophic growth and biomass productivity in BBM were described previously [27]. Microalga was maintained on the plates with standard BBM [56], supplemented with kanamycin $\left(50 \mu \mathrm{g} \cdot \mathrm{mL}^{-1}\right)$ and ampicillin $\left(10 \mu \mathrm{g} \cdot \mathrm{mL}^{-1}\right)$. All manipulations were performed under sterile conditions to avoid contamination. Soil extract and vitamin mix were not added to the original BBM.

Before starting experiments in a photobioreactor, the alga was grown in $250 \mathrm{~mL}$ glass Erlenmeyer flasks containing $30 \mathrm{~mL}$ of autoclaved standard BBM. The cells were cultivated for five days on the shaker at $120 \mathrm{rpm}$ at $28{ }^{\circ} \mathrm{C}$ and under continuous illumination of $200 \mu \mathrm{mol} \cdot \mathrm{m}^{-2} \cdot \mathrm{s}^{-1}$. The collected inoculum was then transferred to a sterilized 3.6 L Labfors 4 Lux photobioreactor (Infors HT, Bottmingen, Switzerland) with a working volume of $2.4 \mathrm{~L}$ with controlled luminous flux levels (Figure 6). An initial $\mathrm{OD}_{750}$ (optical density at $750 \mathrm{~nm}$ ) of 0.01 was achieved.



Figure 6. The Labfors 4 Lux photobioreactor (Infors HT, Switzerland) used in this study.

In these experiments, to select the optimal concentration of digestate, we cultured algal cells at $28 \pm 0.5^{\circ} \mathrm{C}$, under illumination at $1200 \mu \mathrm{mol}$ photons $\mathrm{m}^{-2} \cdot \mathrm{s}^{-1}$, and with sparging of atmospheric air containing $2.0 \%$ carbon dioxide. A modified BBM with an ammonium nitrogen source $\left(\mathrm{NH}_{4} \mathrm{Cl}\right)$ was additionally used to compare growth efficiency (final concentrations of ammonium, phosphate, and sulfate ions were $\sim 250, \sim 160$, and 
$\sim 40 \mathrm{mg} \cdot \mathrm{L}^{-1}$, respectively). An amount of $1.3 \mathrm{~L} \cdot \mathrm{min}^{-1}$ aeration was provided by a compressor. The addition of carbon dioxide was provided by a thermal mass flow controller (Vögtlin Instruments, Aesch, Switzerland). Air and carbon dioxide were mixed and then added to the photobioreactor through a $0.45 \mu \mathrm{m}$ filter. The photobioreactor was continuously stirred at $120 \mathrm{rpm}$. The light was maintained on a 16:8 light/dark cycle. $\mathrm{pH}$ was measured with an EasyFerm Plus PHI K8 200 electrode (Hamilton, USA) throughout the whole experimental period. In experiments with controlled $\mathrm{pH}$, sterilized $8 \% \mathrm{NaOH}$ or $8 \%$ $\mathrm{HCl}$ were used. When observing the foam, a sterile $2 \%$ solution of antifoam (Antifoam B, Sigma-Aldrich, St. Louis, MO, USA) was added to the reactor. Specific growth rate $\left(\right.$ day $\left.^{-1}\right)$ and biomass productivity $\left(\mathrm{g} \cdot \mathrm{L}^{-1} \cdot\right.$ day $\left.^{-1}\right)$ were calculated as described previously [57].

Two independent experiments were performed to test reproducibility, and the results are presented as mean values.

\subsection{Analytical Methods}

During the growth of microalga, samples were taken from the photobioreactor every $16-24 \mathrm{~h}$ to determine the growth, the concentration of pigments in cells, $\mathrm{pH}$ changes, and to evaluate the efficiency of nutrient removal by $C$. sorokiniana AM-02 under the tested cultivation conditions.

Optical density (OD) at $750 \mathrm{~nm}$ (using cell-free culture medium as reference) and the number of cells were measured every 16-24 h as previously described [27]. After each experimental period, the biomass was collected by centrifugation at $5000 \times g$ for $10 \mathrm{~min}$.

The final biomass yield (dry weight) and volatile solids were analyzed using a drying oven (at $105^{\circ} \mathrm{C}$ for $20 \mathrm{~h}$ ) and a muffle oven (at $550{ }^{\circ} \mathrm{C}$ for $2 \mathrm{~h}$ ), respectively. Chlorophylls a and $b$, carotenoids, and total pigments $\left(\mathrm{mg} \cdot \mathrm{L}^{-1}\right)$ were determined using dimethyl sulfoxide extraction and optical absorption correlation, as previously described by Wellburn [58].

The concentration of ammonium ions in the medium was determined by the photometric method. Briefly, samples were centrifuged at $10,000 \times g$ for $5 \mathrm{~min}$. The supernatant was diluted with distilled water, and $100 \mu \mathrm{L}$ of Nessler's reagent (Sigma-Aldrich, St. Louis, MO, USA) was added to each tube and mixed. The tubes were kept for 10 min in the dark, and the optical density was measured at $425 \mathrm{~nm}$ using a Lambda 35 spectrophotometer (Perkin Elmer, Singapore).

Ion chromatography was also performed to analyze the bioremediation potential of C. sorokiniana AM-02 in terms of utilization of phosphate and sulfate ions. Anion concentration was measured using a Dionex ICS-900 Ion Chromatography System (Thermo Fisher Scientific), as described previously [27]. Nutrient removal efficiency was calculated, as described previously [12].

All measurements were performed in triplicate with two replicates of each experiment. Tukey multiple comparison test was used to compare differences (Minitab software version 20.1.0.0).

\subsection{Bacterial Community Structure Analysis}

At the end of each ADE-containing experiment, samples were taken to analyze bacterial communities' structure (only one biological replicate was investigated). DNA was extracted and purified from samples after centrifugation of $10 \mathrm{~mL}$ at $14,000 \times g$ for $10 \mathrm{~min}$ using a FastDNA spin kit (MP Biomedical, Solon, OH, USA), according to the manufacturer's protocol. Extracted DNA was then quantified with a Qubit 2.0 Fluorometer (Invitrogen, Carlsbad, CA, USA). Primers Bakt_341F (5'-CCT ACG GGN GGC WGC AG-3') and Bakt_805R (5'-GAC TAC HVG GGT ATC TAA TCC-3') were used to amplify the bacterial 16S rRNA gene. Negative extraction control samples did not give visible amplicons, and therefore, they were not analyzed further. Each sample was amplified in triplicate ( 25 cycles). Sequencing was completed by using an Illumina MiSeq Kit v3 (600 cycles) according to the manufacturer's instructions. Sequencing of the 16S rRNA gene was conducted in duplicate to ensure reproducibility (two technical replicates were obtained). Additionally, we tried to extract DNA from the pretreated ADE (supernatant), but the DNA 
concentration was low. This did not allow us to amplify the bacterial 16S rRNA gene in the amounts required for further amplicon sequencing.

The obtained sequence data were then analyzed with the Quantitative Insights into Microbial Ecology (QIIME) software package [59]. High-quality 16S rRNA gene sequences were clustered into OTUs (clustering threshold is $97 \%$ identity). OTUs representing less than $0.1 \%$ of the total reads were also excluded. Alpha diversity indices were assessed on an OTU level. For the taxonomic assignment of bacterial OTUs, the Silva database was used [60].

\section{Conclusions}

Finally, this work explored whether agricultural wastewater obtained after the anaerobic digestion could replace conventional feedstock in biomass production from Chlorella sorokiniana AM-02. The results show that agrarian waste materials are a suitable replacement for traditional media; however, the level of nutrients in these media, such as phosphate and sulfate, must also be controlled to maintain adequate growth of green microalgae. Results showed that $C$. sorokiniana AM-02 is capable of active growth, productivity, and utilization of nutrients in a source of low-quality water. Thus, C. sorokiniana AM-02 grew well under $10-40 \%(v / v)$ anaerobic digestion effluent loading, with the highest growth rate being 1.45 day $^{-1}$ obtained at $10 \%$ effluent loading (with the addition of phosphate and sulfate ions). The highest biomass productivity of $0.50 \mathrm{~g} \cdot \mathrm{L}^{-1}$. day ${ }^{-1}$ was obtained with $20 \%$ effluent loading. Besides, microalgae biomass can be considered as animal feed additives or fertilizers.

Author Contributions: Conceptualization, E.E.Z. and A.M.Z.; methodology, E.E.Z. and A.M.Z.; software, E.E.Z., S.S.B. and A.M.Z.; validation, E.E.Z., S.S.B. and A.M.Z.; formal analysis, E.E.Z., S.S.B. and A.M.Z.; investigation, E.E.Z., S.S.B. and A.M.Z.; resources, A.M.Z.; data curation, E.E.Z. and A.M.Z.; writing — original draft preparation, E.E.Z.; writing—review and editing, S.S.B. and A.M.Z.; visualization, E.E.Z. and S.S.B.; supervision, A.M.Z.; project administration, A.M.Z.; funding acquisition, A.M.Z. All authors have read and agreed to the published version of the manuscript.

Funding: The Russian Foundation for Basic Research funded this research, grant number Grant No. 18-34-20002.

Acknowledgments: We would like to thank the technicians within the department of Microbiology at KFU for their support during the undertaking of the project.

Conflicts of Interest: The authors declare no conflict of interest.

\section{References}

1. Hamed, I. The evolution and versatility of microalgal biotechnology: A review. Compr. Rev. Food Sci. Food Saf. 2016, 15, 1104-1123. [CrossRef]

2. Khan, M.I.; Shin, J.H.; Kim, J.D. The promising future of microalgae: Current status, challenges, and optimization of a sustainable and renewable industry for biofuels, feed, and other products. Microb. Cell Fact. 2018, 17, 36. [CrossRef]

3. Kumar, K.S.; Dahms, H.U.; Won, E.J.; Lee, J.S.; Shin, K.H. Microalgae-A promising tool for heavy metal remediation. Ecotoxicol. Environ. Saf. 2015, 113, 329-352. [CrossRef]

4. Silkina, A.; Ginnever, N.E.; Fernandes, F.; Fuentes-Grünewald, C. Large-scale waste bio-remediation using microalgae cultivation as a platform. Energies 2019, 12, 2772. [CrossRef]

5. Ziganshin, A.M.; Ziganshina, E.E.; Byrne, J.; Gerlach, R.; Struve, E.; Biktagirov, T.; Rodionov, A.; Kappler, A. Fe(III) mineral reduction followed by partial dissolution and reactive oxygen species generation during 2,4,6-trinitrotoluene transformation by the aerobic yeast Yarrowia lipolytica. AMB Express 2015, 5, 8. [CrossRef] [PubMed]

6. Brusseau, M.L.; Pepper, I.L.; Gerba, C.P. Environmental and Pollution Science, 3rd ed.; Academic Press: London, UK, 2019; 662p.

7. Whitton, R.; Ometto, F.; Pidou, M.; Jarvis, P.; Villa, R.; Jefferson, B. Microalgae for municipal wastewater nutrient remediation: Mechanisms, reactors and outlook for tertiary treatment. Environ. Technol. Rev. 2015, 4, 133-148. [CrossRef]

8. Hom-Diaz, A.; Jaén-Gil, A.; Bello-Laserna, I.; Rodríguez-Mozaz, S.; Vicent, T.; Barceló, D.; Blánquez, P. Performance of a microalgal photobioreactor treating toilet wastewater: Pharmaceutically active compound removal and biomass harvesting. Sci. Total Environ. 2017, 592, 1-11. [CrossRef]

9. Umamaheswari, J.; Shanthakumar, S. Efficacy of microalgae for industrial wastewater treatment: A review on operating conditions, treatment efficiency and biomass productivity. Rev. Environ. Sci. Biotechnol. 2016, 15, 265-284. [CrossRef] 
10. Wang, Y.; Ho, S.H.; Cheng, C.L.; Guo, W.Q.; Nagarajan, D.; Ren, N.Q.; Lee, D.J.; Chang, J.S. Perspectives on the feasibility of using microalgae for industrial wastewater treatment. Bioresour. Technol. 2016, 222, 485-497. [CrossRef]

11. Yadav, G.; Dash, S.K.; Sen, R. A biorefinery for valorization of industrial waste-water and flue gas by microalgae for waste mitigation, carbon-dioxide sequestration and algal biomass production. Sci. Total Environ. 2019, 688, 129-135. [CrossRef]

12. Bohutskyi, P.; Liu, K.; Nasr, L.K.; Byers, N.; Rosenberg, J.N.; Oyler, G.A.; Betenbaugh, M.J.; Bouwer, E.J. Bioprospecting of microalgae for integrated biomass production and phytoremediation of unsterilized wastewater and anaerobic digestion centrate. Appl. Microbiol. Biotechnol. 2015, 99, 6139-6154. [CrossRef]

13. Bohutskyi, P.; Kligerman, D.C.; Byers, N.; Nasr, L.K.; Cua, C.; Chow, S.; Su, C.; Tang, Y.; Betenbaugh, M.J.; Bouwer, E.J. Effects of inoculum size, light intensity, and dose of anaerobic digestion centrate on growth and productivity of Chlorella and Scenedesmus microalgae and their poly-culture in primary and secondary wastewater. Algal Res. 2016, 19, 278-290. [CrossRef]

14. Fan, J.; Chen, Y.; Zhang, T.C.; Ji, B.; Cao, L. Performance of Chlorella sorokiniana-activated sludge consortium treating wastewater under light-limited heterotrophic condition. Chem. Eng. J. 2020, 382, 122799. [CrossRef]

15. Chen, C.Y.; Kuo, E.W.; Nagarajan, D.; Ho, S.H.; Dong, C.D.; Lee, D.J.; Chang, J.S. Cultivating Chlorella sorokiniana AK-1 with swine wastewater for simultaneous wastewater treatment and algal biomass production. Bioresour. Technol. 2020, 302, 122814. [CrossRef] [PubMed]

16. Kobayashi, N.; Noel, E.A.; Barnes, A.; Watson, A.; Rosenberg, J.N.; Erickson, G.; Oyler, G.A. Characterization of three Chlorella sorokiniana strains in anaerobic digested effluent from cattle manure. Bioresour. Technol. 2013, 150, 377-386. [CrossRef]

17. Kwon, G.; Nam, J.H.; Kim, D.M.; Song, C.; Jahng, D. Growth and nutrient removal of Chlorella vulgaris in ammonia-reduced raw and anaerobically-digested piggery wastewaters. Environ. Eng. Res. 2020, 25, 135-146. [CrossRef]

18. Mujtaba, G.; Lee, K. Treatment of real wastewater using co-culture of immobilized Chlorella vulgaris and suspended activated sludge. Water Res. 2017, 120, 174-184. [CrossRef]

19. Sepehri, A.; Sarrafzadeh, M.-H.; Avateffazeli, M. Interaction between Chlorella vulgaris and nitrifying-enriched activated sludge in the treatment of wastewater with low C/N ratio. J. Clean. Prod. 2020, 247, 119164. [CrossRef]

20. Kumbhar, A.N.; He, M.; Rajper, A.R.; Memon, K.A.; Rizwan, M.; Nagi, M.; Woldemicael, A.G.; Li, D.; Wang, C.; Wang, C. The use of urea and kelp waste extract is a promising strategy for maximizing the biomass productivity and lipid content in Chlorella sorokiniana. Plants 2020, 9, 463. [CrossRef]

21. Metsoviti, M.N.; Papapolymerou, G.; Karapanagiotidis, I.T.; Katsoulas, N. Effect of light intensity and quality on growth rate and composition of Chlorella vulgaris. Plants 2020, 9, 31. [CrossRef] [PubMed]

22. Puglisi, I.; Barone, V.; Fragalà, F.; Stevanato, P.; Baglieri, A.; Vitale, A. Effect of microalgal extracts from Chlorella vulgaris and Scenedesmus quadricauda on germination of Beta vulgaris seeds. Plants 2020, 9, 675. [CrossRef] [PubMed]

23. Uggetti, E.; Sialve, B.; Trably, E.; Steyer, J.P. Integrating microalgae production with anaerobic digestion: A biorefinery approach. Biofuels Bioprod. Bioref. 2014, 8, 516-529. [CrossRef]

24. Sekine, M.; Yoshida, A.; Akizuki, S.; Kishi, M.; Toda, T. Microalgae cultivation using undiluted anaerobic digestate by introducing aerobic nitrification-desulfurization treatment. Water Sci. Technol. 2020, 82, 1070-1080. [CrossRef]

25. Ziganshin, A.M.; Ziganshina, E.E.; Kleinsteuber, S.; Pröter, J.; Ilinskaya, O.N. Methanogenic community dynamics during anaerobic utilization of agricultural wastes. Acta Nat. 2012, 4, 91-97. [CrossRef]

26. Ziganshin, A.M.; Wintsche, B.; Seifert, J.; Carstensen, M.; Born, J.; Kleinsteuber, S. Spatial separation of metabolic stages in a tube anaerobic baffled reactor: Reactor performance and microbial community dynamics. Appl. Microbiol. Biotechnol. 2019, 103, 3915-3929. [CrossRef]

27. Ziganshina, E.E.; Bulynina, S.S.; Ziganshin, A.M. Comparison of the photoautotrophic growth regimes of Chlorella sorokiniana AM-02 in a photobioreactor for enhanced biomass productivity. Biology 2020, 9, 169. [CrossRef]

28. Cai, T.; Park, S.Y.; Racharaks, R.; Li, Y. Cultivation of Nannochloropsis salina using anaerobic digestion effluents a nutrient source for biofuel production. Appl. Energy. 2013, 108, 486-492. [CrossRef]

29. Collos, Y.; Harrison, P.J. Acclimation and toxicity of high ammonium concentrations to unicellular algae. Mar. Pollut. Bull. 2014, 80, 8-23. [CrossRef] [PubMed]

30. Markou, G.; Georgakakis, D. Cultivation of filamentous cyanobacteria (blue-green algae) in agro-industrial wastes and wastewaters: A review. Appl. Energy 2011, 88, 3389-3401. [CrossRef]

31. Depraetere, O.; Foubert, I.; Muylaert, K. Decolorisation of piggery wastewater to stimulate the production of Arthrospira platensis. Bioresour. Technol. 2013, 148, 366-372. [CrossRef] [PubMed]

32. Moheimani, N.R.; McHenry, M.P.; de Boer, K.; Bahri, P. Biomass and biofuels from microalgae. In Biofuel Biorefinery Technologies; Springer International Publishing: New York, NY, USA, 2015.

33. Zhu, L.; Wang, Z.; Shu, Q.; Takala, J.; Hiltunen, E.; Feng, P.; Yuan, Z. Nutrient removal and biodiesel production by integration of freshwater algae cultivation with piggery wastewater treatment. Water Res. 2013, 47, 4294-4302. [CrossRef] [PubMed]

34. Arumugam, M.; Agarwal, A.; Arya, M.C.; Ahmed, Z. Influence of organic waste and inorganic nitrogen source on biomass productivity of Scenedesmus and Chlorococcum sp. Int. J. Energy Environ. 2012, 2, 1125-1132.

35. Hulatt, C.J.; Lakaniemi, A.M.; Puhakka, J.A.; Thomas, D.N. Energy demands of nitrogen supply in mass cultivation of two commercially important microalgal species, Chlorella vulgaris and Dunaliella tertiolecta. Bioenergy Res. 2012, 5, 669-684. [CrossRef]

36. Lizzul, A.; Hellier, P.; Purton, S.; Baganz, F.; Ladommatos, N.; Campos, L. Combined remediation and lipid production using Chlorella sorokiniana grown on wastewater and exhaust gases. Bioresour. Technol. 2014, 151, 12-18. [CrossRef] 
37. De-Bashan, L.E.; Bashan, Y. Immobilized microalgae for removing pollutants: Review of practical aspects. Bioresour. Technol. 2010, 101, 1611-1627. [CrossRef]

38. Wang, Y.; Ho, S.-H.; Cheng, C.-L.; Nagarajan, D.; Guo, W.-Q.; Lin, C.; Li, S.; Ren, N.; Chang, J.-S. Nutrients and COD removal of swine wastewater with an isolated microalgal strain Neochloris aquatica CL-M1 accumulating high carbohydrate content used for biobutanol production. Bioresour. Technol. 2017, 242, 7-14. [CrossRef]

39. Oswald, W.J.; Asce, A.M.; Gotaas, H.B. Photosynthesis in sewage treatment. Trans. Am. Soc. Civ. Eng. 1957, 122, 73-105. [CrossRef]

40. Seymour, J.; Amin, S.; Raina, J.B.; Stocker, R. Zooming in on the phycosphere: The ecological interface for phytoplankton-bacteria relationships. Nat. Microbiol. 2017, 2, 17065. [CrossRef]

41. Balkwill, D.L.; Fredrickson, J.K.; Romine, M.F. Sphingomonas and related genera. In The Prokaryotes, 3rd ed.; Dworkin, M., Falkow, S., Rosenberg, E., Schleifer, K.H., Stackebrandt, E., Eds.; Springer: New York, NY, USA, 2006; Volume 7, pp. 605-629.

42. Song, J.; Joung, Y.; Li, S.H.; Hwang, J.; Cho, J.C. Sphingobacterium chungjuense sp. nov., isolated from a freshwater lake. Int. J. Syst. Evol. Microbiol. 2020. [CrossRef]

43. Son, S.-W.; Chang, H.-W.; Kim, S.K.; Chang, J.-S. Sphingobacterium sp. SW-09 effectively degrades phenanthrene, a polycyclic aromatic hydrocarbon, in a soil microcosm. J. Life Sci. 2011, 21, 1511-1517. [CrossRef]

44. Ryan, M.P.; Pembroke, J.T. Brevundimonas spp: Emerging global opportunistic pathogens. Virulence 2018, 9, 480-493. [CrossRef]

45. M'rassi, A.G.; Bensalah, F.; Gury, J.; Duran, R. Isolation and characterization of different bacterial strains for bioremediation of n-alkanes and polycyclic aromatic hydrocarbons. Environ. Sci. Pollut. Res. Int. 2015, 22, 15332-15346.

46. Wang, X.; Wang, X.; Liu, M.; Zhou, L.; Gu, Z.; Zhao, J. Bioremediation of marine oil pollution by Brevundimonas diminuta: Effect of salinity and nutrients. Desalin. Water Treat. 2016, 57, 19768-19775. [CrossRef]

47. Matu, A.; Lum Nde, A.; Oosthuizen, L.; Hitzeroth, A.; Badenhorst, M.; Duba, L.; Gidaga, M.; Klinck, J.; Kriek, I.M.; Lekoma, P.J.; et al. Draft genome sequences of seven Chryseobacterium type strains. Microbiol. Resour. Announc. 2019, 8, e01518-18. [CrossRef] [PubMed]

48. Ramírez-García, R.; Gohil, N.; Singh, V. Chapter 21-Recent advances, challenges, and opportunities in bioremediation of hazardous materials. In Phytomanagement of Polluted Sites; Pandey, V.C., Bauddh, K., Eds.; Elsevier: Amsterdam, The Netherlands, 2019; pp. 517-568.

49. Kämpfer, P.; Schulze, R.; Jäckel, U.; Malik, K.A.; Amann, R.; Spring, S. Hydrogenophaga defluvii sp. nov. and Hydrogenophaga atypica sp. nov., isolated from activated sludge. Int. J. Syst. Evol. Microbiol. 2005, 55, 341-344.

50. Waśkiewicz, A.; Irzykowska, L. Flavobacterium spp.-Characteristics, occurrence, and toxicity. In Encyclopedia of Food Microbiology, 2nd ed.; Batt, C.A., Tortorello, M.L., Eds.; Academic Press: London, UK, 2014; pp. 938-942.

51. Ivshina, I.B.; Kuyukina, M.S.; Krivoruchko, A.V. Chapter 6-Hydrocarbon-oxidizing bacteria and their potential in ecobiotechnology and bioremediation. In Microbial Resources; Kurtböke, I., Ed.; Academic Press: London, UK, 2017 ; pp. 121-148.

52. Bell, T.A.S.; Prithiviraj, B.; Wahlen, B.D.; Fields, M.W.; Peyton, B.M. A Lipid-accumulating alga maintains growth in outdoor, alkaliphilic raceway pond with mixed microbial communities. Front. Microbiol. 2015, 6, 1480. [CrossRef]

53. Steichen, S.A.; Gao, S.; Waller, P.; Brown, J.K. Association between algal productivity and phycosphere composition in an outdoor Chlorella sorokiniana reactor based on multiple longitudinal analyses. Microb. Biotechnol. 2020, 13, 1546-1561. [CrossRef]

54. Ziganshina, E.E.; Belostotskiy, D.E.; Bulynina, S.S.; Ziganshin, A.M. Influence of granular activated carbon on anaerobic codigestion of sugar beet pulp and distillers grains with solubles. Processes 2020, 8, 1226. [CrossRef]

55. Ziganshina, E.E.; Belostotskiy, D.E.; Bulynina, S.S.; Ziganshin, A.M. Effect of magnetite on anaerobic digestion of distillers grains and beet pulp: Operation of reactors and microbial community dynamics. J. Biosci. Bioeng. 2021. [CrossRef]

56. Nichols, H.W.; Bold, H.C. Trichosarcina polymorpha Gen. et Sp. Nov. J. Phycol. 1965, 1, 34-38. [CrossRef]

57. Lizzul, A.M.; Lekuona-Amundarain, A.; Purton, S.; Campos, L.C. Characterization of Chlorella sorokiniana, UTEX 1230. Biology 2018, 7, 25. [CrossRef] [PubMed]

58. Wellburn, A.R. The spectral determination of chlorophylls $a$ and $b$, as well as total carotenoids, using various solvents with spectrophotometers of different resolution. J. Plant Physiol. 1994, 144, 307-313. [CrossRef]

59. Caporaso, J.G.; Kuczynski, J.; Stombaugh, J.; Bittinger, K.; Bushman, F.D.; Costello, E.K.; Fierer, N.; Pena, A.G.; Goodrich, J.K.; Gordon, J.I. QIIME allows analysis of high-throughput community sequencing data. Nat. Methods 2010, 7, 335-336. [CrossRef] [PubMed]

60. Quast, C.; Pruesse, E.; Yilmaz, P.; Gerken, J.; Schweer, T.; Yarza, P.; Peplies, J.; Glöckner, F.O. The SILVA ribosomal RNA gene database project: Improved data processing and web-based tools. Nucleic Acids Res. 2013, 41, D590-D596. [CrossRef] [PubMed] 